\title{
Syria's ordeal: A modern state's disintegration in an age of fake news and superpower regional rivalry
}

\begin{abstract}
The negative impact of globalization is readily observed in today's Syria. Ravished by seven years of internal conflict stimulated initially by Tunisia's Arab awakening, this once proud state has become a magnet for religious fanatics and their wealthy sponsors in conservative Saudi Arabia and other countries far and near seeking geopolitical advantage. Not least Syria has experienced the seemingly futile endeavors by those in the United Nations and elsewhere seeking a solution to this country's enduring turmoil. Military intervention by Iran and Russia has changed the configuration of the conflict at the critical point in time when Israeli and American intervention provides a dangerous environment for superpower conflict. All the while, Syrians remaining in the country suffer, and those seeking safety elsewhere are threatening to destabilize Lebanon, Turkey and Jordan and, farther afield, the cohesion of the European Community.
\end{abstract}

Keywords: Syria, Iran, Turkey, Israel, Arab Spring, terrorism, regional geopolitics, Kurdish problem, refugees, superpower confrontation.

\section{Syria's ordeal}

In the eyes of many, the Middle East has been the scene of many a recent tragedy. How best to define the words tragedy and recent opens up the proverbial Pandora's box. For the purposes of this paper, the Armenian Genocide ${ }^{1}$ in mid-World War I

${ }^{1}$ The Armenian displacements and deaths during the early years of World War I, particularly in 1915, continues to sour relations with the successor government to the Ottoman Regime in power at the time of this tragic event. Was it genocide or harsh actions caused in part by Russia's invasion and suspected cooperation by Armenians in eastern Anatolia? The latter is the rationale most often employed by the present regime in Turkey. Conversely, there is ample evidence that longstanding distrust and distaste for the Ottoman Empire's Armenian community, coupled with wartime issues, provided the opportunity for the regime to finally settle the issue by destroying this sizeable Christian community.

The American Ambassador to Constantinople at the time of the massacres leaves no doubt as to who was responsible. His Chapter 24 'The Murder of a Nation' in Ambassador Morgenthau's Story (Morgenthau 1918) is a horrific compendium of events reported to him by American consular officials and other sources. It is not easy reading - rape, murder, starvation and death marches into the Syrian Desert coupled with the grabbing-up 
is as good a starting point as any. To this day, the official Turkish explanation disclaims genocide - a position increasingly at odds with significant world opinion $^{2}$. The Turks fare better in the case of how outsiders view the expulsion of the historic Greek-speaking community in western Anatolia after Greek troops arrived, when the Ottoman order was disintegrating and Turkish nationalism not fully developed (Milton 2008). In hindsight, flawed as the Treaty of Versailles proved to be for Europe and elsewhere, denying the Kurds their own state in the never ratified 1920 Treaty of Sevres ${ }^{3}$ has been the kernel of rapidly growing discontent in a region stretching from northern Iran to the Mediterranean.

Those who attempt to justify the official rationale behind the American-led coalition to depose Saddam Hussein and devastate Iraq are akin to a vanishing species. Even the earlier intervention to remove Iraqi forces from Kuwait seems not to be as black and white as once thought to be the case. There has been

of attractive Armenian females for slavery and concubines by Kurds whose voraciousness was encouraged by the regime. A German medical officer Armin T. Weigner against orders compiled a photographic compendium of what he witnessed in 1915 while stationed along the Berlin-to-Baghdad railway in the vicinity of Deir-es-Zor. His photographs provide a visual reminder of the horrific events of the time ("Wegner Photo Collection" - Armenian National Institute, www.armenian genocide.org, Washington D.C). Chancellor Adolph Hitler, in an August 22, 1939 speech to senior army (Wehrmacht) officers in his Obersaltzburg home is purportedly to have ended the speech that dealt with proposed forthcoming harsh treatment of Poles in the soon-to-commence conflict by stating "Who, after all, speaks today of the annihilation of the Armenians?" (Lochner 1942). Lochner claimed to have received a copy of this speech while in Berlin. The post war Nuremburg Tribunal received his copy as well as others from different sources. Questions of authenticity arose due to the fact that Hitler apparently gave two speeches that day and only one had the Armenian Genocide reference.

2 The Armenian National Institute in Washington, D.C. identifies countries that recognize the Armenian Genocide. While few in number these countries include most of Europe (Austria, Belgium, Cyprus, Czech Republic, Denmark, France, Germany, Greece, Italy, Lithuania, Luxemburg, Netherlands, Russia, Poland, Slovakia, Sweden, Switzerland and Vatican City), Canada and the United States, Lebanon and several Latin America states (Argentina, Bolivia, Brazil, Chile, Paraguay, Venezuela and Uruguay). Aside from Lebanon, notably absent from the list are countries with significant Muslim populations; Asian and sub-Asian countries and Africa south of the Sahara.

3 "Treaty of Sevres August 10, 1920 - Protection of Minorities Articles 140-151". World War I Document Archive, Brigham Young University, Provo, Utah. Also: W.D. Durham (2010). Durham suggests that British and postwar Turkish geostrategies coupled with concern for Soviet expansion into Halford MacKinder's 'Eurasian Heartland' outweighed a proliferation of newly minted mini-states in the region. The Kurdish 'problem' continues. An op ed piece in the "International New York Times" September 27, 2018 by Aliza Marcus notes that our Kurdish allies in Syria "are not disposable allies". She chastises Washington for not providing the Kurds in Syria political backing against Turkish intrusions as well as weapons support. 
speculation that hidden in state documents is possible evidence to support the theory that Kuwait's intransigence regarding seemingly reasonable Iraqi demands had its origin in the West and were designed to goad Iraq into invading Kuwait. The decade long Iraqi-Iranian conflict assuaged doubts of those who feared a resurgent Iran or a too militarily powerful $\mathrm{Iraq}^{4}$. The always present Palestinian-Israeli problem brought the United States into the region but hardly as an impartial actor $^{5}$. Indeed, protecting questionable Israeli actions by blocking UN Security

${ }^{4}$ The conflict between Iraq and Iran began in September 1980 and lasted eight years; it was started by Iraq's Saddam Hussein who feared Iran's Islamic revolution and new leader Ayatollah Khomeini. The initial cause likely was the earlier, pre-Islamic Revolution, and favorable-to-Iran demarcation of the Shatt al-Arab waterway separating the two countries that constricted Iraq's oil exports. Iran, for its part, condemned Iraq's treatment of its Shia majority population. What was meant to be a short conflict dragged on and exhausted both countries. The United States provided aerial intelligence supporting both sides depending on which country was in the ascendancy and possibly helped to prepare the groundwork for the First Gulf War a few years later. The financial costs to both countries were massive and, in Iraq's case, partially alleviated by donations from other Arab oil-producing countries. That Kuwait later insisted that its financial support was loans and not donations was a factor in Iraq's later invasion. Besides mutual exhaustion, it was attacks on other countries' oil tankers that got Washington directly involved by providing temporary U.S. Registration and implied military protection for Kuwati tankers (Hardy 2005). The seminal assessment of this eight year conflict and what led to it is Robert Fisk's The Great War for Civilization: The Conquest of the Middle East (2006). Chapters Five 'The Path to War' and Six 'The Whirlwind War,' p. 139-217, provide in-depth details of events. Fisk a foreign journalist witnessed first-hand many of the tumultuous events in the war.

${ }^{5}$ Washington's support for Israel is longstanding but recently has reached a point where neutrality in the Palestinian-Israeli conflict has been replaced by blatant support for one side. There are numerous components to this support but two stand out: (1) The financially-generated political power of pro-Israeli American Jews and non-Jews by way of individual contributions and especially money provided by AIPAC (The American Israel Public Affairs Committee) for sitting representatives and candidates for election in critical congressional races. The American political system and its single-member congressional districts invite attention and financial support for or against candidates in the earlier political party primary election where votes in Washington concerning Israel are viewed favorably or unfavorably. The scale of AIPAC financial support for particular members of the U.S. Congress is staggering ("Washington Report On Middle East Affairs", American Educational Trust, Washington, nine issues per year). Its "Report Card for the Congress in session" identifies the amount of money provided to members of Congress by name, district and state. Founded in 1951, AIPAC has become a significant power in influencing congressional votes favorable to Israel (and defeating congressional endeavors to punish Israel).

Recent moves by the present administration (2018) to move the American Embassy from Tel Aviv to Jerusalem; the cutting of financial support to the very organization (United Nations Relief and Works Agency for Palestine) established in 1948 with active American participation and support for displaced Palestinians following the war that gave birth to 
Council responses, not to mention massive financial and military support, has fueled no small portion of the region's current instability.

Looking at the larger and still earlier environment one should mention Britain's betrayal of Prince Faisal's hope of sustaining an Arab political position in Damascus and Palestine where Ottoman rule in 1918 was rapidly dissolving ${ }^{6}$.

Israel and in no small measure was the cause of the refugee problem in the first place; and closing the Palestinian Representative Office in Washington. These actions support the increasing bias in Washington against the Palestinian people. (2) One should mention the emotional impact of the World War II Jewish Holocaust on Americans and the still weak but growing political impact of the Arab-American and Muslim-American populations. This almost total transformation of American policy in favor of Israel stands in sharp contrast to policies pursued by previous American administrations and the directives for allocating Ottoman lands established in the San Remo Conference in April, 1920. Here, resolutions passed determining allocation of Class "A" League of Nations mandates for the administration of three former Ottoman territories - Palestine, Syria and Mesopotamia. Syria and Mesopotamia were provisionally recognized as states; Palestine was not (https:// en.wikipedia. org/wiki/San_Remo_conference). For example, Article 22 notes that English, Arabic and Hebrew shall be the official languages of Palestine. Any statement or inscription in Arabic on stamps or money in Palestine shall be repeated in Hebrew and any statement or inscription in Hebrew shall be repeated in Arabic". Whatever their intentions in the early structuring of what might eventually be a Jewish Homeland and how these morphed into an independent Israel where non-Jews are treated as second-class citizens or apartheid-comparable subjects residing in occupied territory is a stark reminder of the victor's progression from survivor to conqueror. Sir Isaiah Berlin commented in 1953 in a lecture at The Royal Society of Arts in London to Members of the Anglo-Israel Association that "The ideals the Jews imported, and the culture they were able to build in the relative vacuum of Palestine - with a minimum of counter-influence on account of the evident feebleness of the Moslem culture in this corner of the Arab world". The Origins of Israel in: W.Z. Laqueur (1958). It must be countered if only in part by J.A. Fayez's The Colonization of Palestine: Lest the Civilized World Forget (2015). Identified by name are 452 depopulated or destroyed Palestinian towns and villages from the 1948 war for Israeli independence; W. Khalidi's Before Their Diaspora: A Photographic History of the Palestinians 1876-1948 (1984); and The Holy Land: Yesterday and Today, Lithographs and Diaries by David Roberts, R.A. (1994). These provide an alternative interpretation to Sir Isaiah Berlin's demeaning assessment of Palestine and its non-Jewish inhabitants before Israel's birth.

${ }^{6}$ World Future Fund (http://www.worldfuturefund.org) - "British Lies to the Arabs in World War I. The McMahon-Hussein Correspondence 1915-1916". The McMahon-Hussein Correspondence, was an exchange of letters (July $14^{\text {th }}, 1915$ - January $30^{\text {th }}$, 1916) during World War I, between the Sharif of Mecca, Husayn bin Ali, and Sir Henry McMahon, British High Commissioner in Egypt, concerning the political status of lands under the Ottoman Empire. "Now the Arab side was already planning a large revolt against the Ottoman Empire; however, the British further encouraged the Arabs to revolt under their direction and command, with promises of independence and their own territory". The Arab view was that Palestine was included in the area promised to them. Conflict with the Balfour Declaration and promises made to the Zionists clearly were an embarrassment to 
The wartime Sykes-Picot agreement between France and Britain assured these two European War allies postwar political control in Syria, Lebanon, Mesopotamia (Iraq) and soon to be created Trans-Jordan (Jordan). Britain gained control over the primary oil producing areas whereas France returned to its historical protection of the Christians?

Mandates assigned after World War I with League of Nations supervision had been otherwise and the promise made earlier by the British High Commissioner in Egypt to Prince Faisal's father the Sharif of Hejaz about post-war Arab governance over greater Syria had come to fruition? There was at least one, albeit fragile, alternative in light of the terrible deaths incurred by Britain and France during the war. This was an endeavor by President Wilson to explore alternative options for these former Ottoman lands, The King-Crane Commission ${ }^{8}$. It was an outgrowth of the Paris Peace Conference and referred to as the 1919 Inter-Allied Commission on Mandates in Turkey. Begun as an official investigation staffed by the French, British, Italian and Americans, it ended as a sole American endeavor as the other countries withdrew to avoid being confronted with an unfavorable report seconded by their own nationals. Publication was suppressed by the U.S. State Department until December 1922.

The Commission recommended that the coastal area peopled largely by minority Christians, who already had a special administrative relationship under Ottoman rule, and who for many years had been given support by France, not be separated the rest of mostly Muslim Sunni Syria. France soon did just that and the state of Lebanon was born. The Commission also spoke out against the Zionist designs for Palestine and proposals in the controversial 1917 Balfour Declaration. Last but not least, the Commission favored the United States assuming the mandate, one incorporating both Palestine and Syria with an international organization to monitor Jerusalem's holy sites. Nothing came of these and Wilson was physically incapacitated by the time he received the report. Whether

Britain. In 1922 the senior civil servant in the Colonial Office advised his government that "there is sufficient doubt in the matter to make it desirable not to drag the controversy out into the daylight", https://www.balfourproject.org/the-mcmahonpromise

${ }^{7}$ The then secret Sykes-Picot treaty divided certain Ottoman lands into French and British spheres of influence. Britain coveted the primary oil producing regions and France greater Syria. France had to subdue militarily significant local opposition in 1920 amongst Syrians who sought to retain their newly established independent Arab government and in 1946 when they literally burned down the building housing Syria's parliament. Contrary to post-World-War I decisions and allocation of mandates, France in 1920 separated the Christian populations in and about Mt. Lebanon into the new state of Lebanon (Fisk 2012).

${ }^{8}$ W. Laqueur (1969) edited and introductory comments (Document 9: "Recommendations of the King-Crane Commission", August 28, 1919: 23-31 and Document 10: "Memorandum Presented to the King-Crane Commission by the General Syrian Congress", July 2, 1919: 31-33). Also: http://www.hri.org./docs/king-crane-recomm.html 
Wilson would have had the courage to confront Britain and France is something else; America's entry into the war made possible the Allies' final success, but Britain and France suffered more and seemed determined to gain Ottoman lands. The Sykes-Picot agreement and Balfour declaration withstood the test of time and their detractors. The current Middle East is the product of these events. The United States declined to be a member of The League of Nations and Britain's Lloyd George, when faced with the possible option of having to offend France by not supporting its claim to Syria, commented that "the friendship of France is worth ten Syrias" ". France's pending takeover of former Ottoman Syria was not popular with the local inhabitants, whose views and petitions were collected by the King-Crane Commission in $1919^{10}$.

When threatened by the rise of Hitler and fearful of Turkey making common cause with Germany, the French sought to align Ankara to the Allied cause in the looming conflict by ceding the Alexandretta (Iskenderun in today's Turkey) region $^{11}$ to the Turks who had long coveted it. Needless to say, Syrian leaders had no say in this transaction and Turkey chose neutrality in the war. Alexandretta was the historical maritime outlet for Syria's Aleppo region.

Where does Syria fit into this mosaic? Perhaps more importantly, how does Syria's relatively moderate religious outlook function in a region where the religious extreme of Islam is held by the most important of the two wealthiest oil sheikdoms? There is evidence that ultra conservative Saudi clerics and their followers provided monetary and logistical support to jihadists from the Middle East and Western Europe to wreak havoc against those supporting the Assad regime $^{12}$. Turkey openly called for the end of the government in Damascus, thus

\footnotetext{
${ }^{9}$ https://en.wikipedia.org/wiki/King-Crane_Commission
}

${ }^{10}$ During the Commission's tour of Palestine and Syria June 10 - July 21, 1919, "[...] 1,875 petitions were received from local inhabitants. The vast majority favored an independent Syria free of any French mandate and 72\% were hostile to the Zionist plan for a Jewish national home in Palestine", https://www.britannica.com/topic/King-Crane-Commission

${ }^{11}$ Iskenderun (Alexandretta) was one of two pieces of Syrian territory removed during the period of French control: Lebanon in 1920 to provide Christians with their own state and Alexandretta in 1939 to induce Turkey to join the Allied cause at the start of World War II, (Fisk, Ibid.). France's bias in favor of Lebanon's Christians is seen in the country's constitution which states that the president must be Christian, the Prime Minister a Sunni and the Speaker of the Parliament a Shia. The United States copied the spirit of this formula in post-Saddam Hussein Iraq when the three critical posts in the country's parliament were assigned to a Sunni, a Shia and a Kurd. The two situations differ inasmuch as the last census in Lebanon was in 1932 when Maronite and Orthodox Christians combined might possibly have constituted a majority in the country's French-defined boundary. Most observers are of the opinion that the Shia are now the majority population and have been for many years.

${ }^{12}$ In 2013 Syria's Ministry of Information released a disturbing propaganda video "Terror against Syria" produced by the Public Authority for Radio and Television 
enabling jihadists to use Istanbul's airports and land routes for access to northern Syria. Undercutting ecumenical toleration throughout Syrian society clearly was an objective stated or otherwise of this invasion. Others sought to give birth to a new, less oppressive regime using the Arab Spring and lingering opposition to the regime for justification ${ }^{13}$.

The late Hafez al-Assad took control of Syria in a bloodless 1971 military coup; his family and supporters have managed to maintain control over most of the country in spite of a ferocious civil conflict, and much of the world's disdain for its actions and even its legitimacy. Assad's regime never endeared itself to Washington, primarily because it opposed Israel and its policies in what had once been Palestine. The elder Assad was an Arab, an outspoken nationalist for Arab causes who led his country into two of the three wars between Syria and Israel. These actions led to the loss of the strategic Golan Heights to Israel in 1967. The late father and his son are not religious fundamentalists; their religious policies are conspicuous for toleration and in stark contrast to those of some neighboring Arab-speaking states. In 1982, long before the world knew of ISIS, the elder Assad violently crushed a Muslim Brotherhood-inspired uprising in Hama, purportedly killing at least 10,000 insurgents, mostly Sunni. Shortly afterwards, President Hafez Assad gave a speech declaring:

Nothing is more dangerous to Islam than distorting its meanings and concepts while you are posing as a Muslim. This is what the criminal brothers are doing... They are killing in the name of Islam. They are butchering children, women and old people in the name of Islam. They are wiping out entire families in the name of Islam... Death a thousand times to the Muslim Brothers, the criminal Brothers, the corrupt Brothers ${ }^{14}$.

Amongst Syrians joining the fight against their own government were many who were radicalized by the Hama insurrection but also others who sought

depicting horrific scenes in northern Syria where foreign jihadists were fighting. Many of the fighters killed by government forces carried mobile devices visually depicting scenes where individual or group atrocities had taken place. A definitive connection was established between these foreign fighters and their supporters especially in Saudi Arabia.

${ }^{13}$ Can it get together?... "The Economist" (Middle East and Africa) (September 3, 2011: 46). Conflicts between Syrians living abroad for some time and those still in Syria or who left after 2011 were further complicated by the role of Turkey with its Islamist government hosting most of the meetings.

${ }^{14}$ R. Fisk (1997). Quote from a speech by late President Hafez Assad March 7, 1982. Computer Archives Assad Library, Damascus. While strolling through a park near his Damascus hotel, this author noticed couples holding hands, lying together on the grass or participating in family picnics. On another occasion, he joined a gathering sponsored by a local Orthodox priest and the neighboring Sunni imam. Their houses of worship were close together; the task at hand was to neutralize calls by some of their followers to join the fight against Assad rule. 
a more liberal and less oppressive government and certainly one where corruption was less rampant. These latter were often collectively viewed outside of Syria as a liberal opposition to a tyrannical regime. As the conflict progressed with mounting deaths, the internal and external refugee flow to safety and the widespread physical destruction of Syria's cities, many fighters morphed into various factions whose anti-liberal credentials seemed all too familiar to the ones attributed to foreign jihadists. Today, many of the country's Sunni majority continue, if reluctantly, to support Assad rule, as well as overwhelming portions of the country's other important religious groups - Alawite, Orthodox, Armenian, Protestant and Catholic. These people may not like Assad or support all of his policies, but they know too well what the alternative might be if any agreement to end the conflict permitted the radicalized opposition and foreign jihadists a role in governing. Better the devil you know!

President Assad and his late father before him govern one of the more culturally and religiously diverse countries in the Middle East. Maintaining adherence and respect for the national identity in this part of the world is taxing. As elsewhere, corruption also seemed to be a way of life and, as with Tunisia where the 'Arab Spring' began, ending it was a common rallying cry for many of the protesters. Unfortunately, seven years of conflict and endless atrocities and destruction by all combatants have changed some of the original dynamics for protest. Revenge, no quarter and 'die or leave' have assumed a life of their own with increasing internationalization of the conflict.

Syria has also been the focus of widespread condemnation for the use of prohibited chemical weapons. As is so often the case, it is the government in Damascus that is accused of using these weapons, but seldom accused are any of the violent opposition groups. An immediate response to photos showing a collection of dying or critically ill young children in the same room is suspicious. It is possible that the children were collected elsewhere and moved into one room for medical attention or moved there for publicity purposes so as to embarrass the government. There also is the possibility that the government was not responsible. Why would the regime in an earlier attack have gassed its own opposition citizens at the very moment a UN inspection team had arrived on site to ascertain who was responsible for the atrocity? Assad might do stupid things, but he isn't that stupid. Opposition groups are well attuned to the propaganda value of pointing to the regime when chemical attacks occur. Excluding extremists fighting the Assad government from perpetrating some of the chemical weapon attacks is oversimplifying a complex environment in which all parties seek to blame others for terrible acts of violence. That said, there is a body of evidence pointing to the regime in Damascus as having perpetrated many, if not most, of these chemical attacks. A joint investigation by BBC Panorama and BBC Arabic identify the sites of 106 chemical attacks in Syria since September 2013. Particularly damning to the government's public relations agenda is BBC's finding that chlorine chemical 
attacks have increased in marked intensity in those opposition-controlled areas already under intensive artillery and air attack and immediately prior to their surrender ${ }^{15}$. The inference drawn is that chemical attacks by air are the last straw leading to final surrender. Only the regime and Russian allies control the air. Israeli and American aircraft are also there but are not implicated in recent chemical attacks although Israeli planes are known to have dropped phosphorous bombs in Lebanon ${ }^{16}$. President Assad remains adamant that the country's chemical weapons arsenal was surrendered earlier in 2013. Either the president is lying or ill-informed by his own people or, alternatively, certain opposition groups are exceptionally skilled in masking their own chemical weapons potential and is using them to propaganda advantage. This is more likely the case where non-chorine agents such as Sarin have been identified and can be delivered overland.

There arises the question as to why Washington is involved in Syria in the first place. There has been no invitation from Damascus. Perhaps it was the initial success of ISIS in Iraq and its atrocious behavior with well-publicized decapitations and the like; equally plausible is Washington's goal to discourage emerging overland links between Iran and Hezbollah in southern Lebanon and in the process to protect Israel's eastern flank. Neither of the latter justifies a potential worldwide conflict. In light of Washington's current threats of military action against Syria ${ }^{17}$ and Syria's ally to the east, it is appropriate to reassess more accurately the dynamics of this tragic conflict, now in its seventh year, and possibly assign blame for some of the horror.

Libya was to become the second domino in this scenario. Its leadership had earlier given up its nuclear ambitions and had paid substantial money to the families of the deceased for its purported role in the December 1988 Lockerbie Pan Am disaster ${ }^{18}$. The invasion of Muammar Gaddafi's Libya was a classic

${ }^{15}$ N. Al-Maghafi (2018). "The BBC researchers discounted all incidents where there was only one source, or where they concluded there was not sufficient evidence. In all, they determined there was enough credible evidence to be confident a chemical weapon was used in 106 incidents. The BBC team were not allowed access to film on the ground in Syria and could not visit the scenes of reported incidents, and therefore were not able to categorially verify the evidence...", https://www.bbc.com/news/world/middle_east

${ }^{16}$ While at the University of South Carolina, the writer sat on a doctoral committee examination of a young Lebanese student who recounted in detail suffering a painful wound from such a weapon delivered by an Israeli aircraft. At the time, he was living in Lebanon's upper Bekka Valley. He heard the plane and explosion and readily connected it to his personal wound. The student is Dr Naim Salem who, at this writing, is on the faculty at Notre Dame College in Beirut, Lebanon.

${ }^{17}$ Trump warns Syria not to 'recklessly' attack Idlib Province, "The Daily Star" (Beirut), September 4, 2018.

${ }^{18}$ New Lockerbie Report says Libyan (Abdelbaset al-Megrahi) was framed to conceal real bombers, "The Independent" (London), March 11, 2014. This report claims that the downing of the Pan Am plane was originally concocted by Iran's supreme leader Ayatollah 
military operation with air attacks, misinformation and journalists doubling as intelligence agents - all influencing Damascus in its concept of how its emerging civil war would be reported to the outside world. The international press was not permitted into Regime-controlled Syria. In hindsight, leaving the field to the opposition went a long way in setting the stage for what has been too frequently a distorted reporting of a complicated conflict. The U.K.-based Syrian Observatory for Human Rights comprises exiles, and informative as is much of its reporting, clearly represents the anti-Assad opposition in Syria. The internet and iPhones facilitate reporting of news, fake or otherwise. Western journalists venturing into Syria from opposition - controlled areas quickly had second thoughts after the emergence of ISIS and some well-publicized beheadings. As less violent opposition groups stopped fighting or joined more violent emergent organizations, Syrians from all faiths and walks of life began voting with their feet ${ }^{19}$, becoming internal and international migrants or consolidating behind the Damascus government. Liberated Syrian women were not about to support a return to the social Dark Ages which clearly was a major tenet of ISIS and its social agenda.

How is it that a revolt by Syrians morphed into something more sinister and almost worldwide in scope? What was the clarion call that brought so many non-Syrians into Syria to do battle? Ultra-conservatives in Saudi Arabia recruited and sponsored any number of volunteers to fight in Syria. Most were provided with iPhones in order that military or other successes could be reported back to their sponsors. Many of these devices were collected from bodies of those killed; thus, Damascus has a visual history of many atrocities. No less important is how these volunteers reached the battlefields of Syria. Unlike jihadists from the Muslim south of Russia and points east who usually used Iraq as a gateway, most Middle

Khomeini in response to the shooting down six months earlier of a scheduled Iranian passenger plane over the Persian Gulf by the American cruiser Vincennes with the death of 290 crew and passengers followed by questionable explanations by the crew of the Vincennes and their being awarded medals. The likely perpetrator was the Popular Front for the Liberation of Palestine-GC at the time housed in Damascus. The 1979 conflict with Saddam Hussein's Iraq was looming and an agreement between President George Bush and Britain's Margaret Thatcher to shift any hint of responsibility away from Syria and Iran was to avoid discouraging Syria from joining the emerging military coalition being organized for the first Gulf War. Al-Megrahi and the Malta connection to the bomb were fabricated, https://www.independent.co.uk/news/uk/crime/new-lockerbie-report-sayslibyan-was-framed-to-conceal-the-real-bombers-9185163.htnl

${ }^{19}$ In 2013 the writer visited a UN Refugee Processing Center in Lebanon's Lower Bekka Valley close to the Syrian border. Long lines of orderly Syrians were awaiting their turn for interviews and housing assignments. A preponderance of female adults with children suggested that some men had joined the fight in Syria. One could only be impressed by the patience and behavior of both children and their parents and the efficiency of the UN personnel. 
Eastern and Western fighters arrived by way of Turkey. Flights to Istanbul were followed by motor vehicle conveyance to the Syrian border and farther south. That such movements were not noticed by the Turkish government is fantasy; Turkey has sought to replace the Assad government in Syria.

Turkey's massive water projects on both the upriver Tigris and Euphrates were undertaken without meaningful consultation with either Bagdad or Damascus. In January 2018, Turkish troops and warplanes in conjunction with allied Arab fighters invaded northwest Syria to force U.S.-trained Kurds to retreat from the Afrin area near the Turkey-Syria border. This brings into better focus the developing political relationship among Turkey, Iran and Russia. It likely can be traced to fear on the part of Turkey and Iran for possible consolidation of their Kurdish minorities into an independent Kurdish political entity. Russia wants to maintain its long-standing role in Syria and welcomes Turkey as a friendly economic cohort as with Iran, while at the same time using the situation to devalue the NATO alliance.

\section{Enter Iran and Russia}

Significant numbers of Iranians began to appear in 2013. It was common knowledge that cheaper hotels in Damascus were temporarily housing these new 'pilgrims'. Tehran clearly was concerned for the survival of the Assad government and the security of its overland communication routes with the Bekka Valley in neighboring Lebanon. It was in southern Lebanon that its Hezbollah allies were concentrated. It is to be recalled that of all the Arab states and militias that fought against Israel since 1948 only Hezbollah could claim a modicum of success when it held Israeli forces to a rough draw in 2006. That it became such a thorn in the Israeli scheme of things is due in large measure to Israel's arrogance and its lengthy occupation of mostly Shia Muslim southern Lebanon following the 1982 invasion of Lebanon to combat the PLO and their allies. Israel stayed too long and alienated the local population. If ever there was a classic model of the unintended consequences of war, the coming of age of Hezbollah to combat the Israeli intruders and their Maronite Christian allies residing in southern Lebanon is an outstanding example. Israel was obliged to retreat from southern Lebanon and, in doing so, to lay the foundation for an increasingly militant Hezbollah determined to arm itself with Iranian assistance. Those extremist Maronite Christians who too closely aligned themselves with the Israeli occupiers and who were involved in the notorious Sabra and Chatila refugee camp massacres in south Beirut were to lose historic communities in southern Lebanon that had long resided in relative tranquility with their Shia neighbors.

Russia returned to Syria in 2015 and in strength. The Assad regime was in serious trouble. Russia was determined not to be caught off-guard by the West as in Libya, where the UN Security Council created a no-fly zone that set the 
stage for the destruction of Gaddafi's government. Not only had the Syrian opposition inside and outside of the country grown in strength but was receiving increasing support from the United States in material and training. It also was being acknowledged as having a world power at its back. At the same time, ISIS had expanded its reach by taking Mosul in Iraq, hence having a fixed base of support for its operations. ISIS was also making significant intrusions into Syria. Russia had retained a minor naval facility near Tartous since it entered the Middle East back in the 1950s to support Egypt's new Aswan Dam project on the Nile River after promised American funding failed to materialize ${ }^{20}$. The Soviet Union was soon to become the primary supplier of military equipment for the Egyptian and Syrian armies.

Fast forward to 2015 and Russia's decision to help save the Assad regime. Once committed, Russia set in motion a massive military airlift to expand existing facilities on Syria's Mediterranean coast. A major military center was in operation with a potent air arm destined to alter the balance of power in Syria by ruthlessly attacking opposition and ISIS targets. Simultaneously, Iranian allied militias comprising Shia fighters from several countries as well as Hezbollah troops were having success on the ground. The geopolitical dynamics were rapidly changing.

Turkey, once determined to see the end of the Assad regime, was now faced with well-trained Syrian Kurdish cadres determined to recover territory in northern Syria occupied by pro-Turkish militias and ISIS. Turkey feared a possible future political juncture of these troops and Kurdish insurgents in Turkey's eastern Anatolia. Complicating matters was the fact that both Turkey and the United States are members of NATO; the Americans for many years have maintained a major air base near Izmir in western Anatolia. Planes stationed there were almost daily attacking ISIS targets in Syria and Iraq. Russian planes from their base in western Syria were hitting many of these same ISIS targets and even more Syrian opposition targets. Israeli planes were striking Iranian and Hezbollah targets and complicating an already confused environment in the air and on the ground. By 2018, and after a botched September 18 shooting down of a Russian electronic intelligence gathering aircraft by Syrian air defense missiles aimed at Israeli planes purportedly using the Russian plane as cover while attacking targets in Syria,

${ }^{20}$ We Don't Give a Dam - The Feud over Financing the Aswan High Dam - Moments in U.S. Diplomatic History, "Association of Diplomatic Studies and Training", June, 2016. In July, 1956, Secretary of State John Foster Dulles notified the Egyptian Ambassador that the United States was withdrawing its earlier offer to help finance the construction of Egypt's Aswan High Dam citing growing Congressional disapproval of Egypt's obtaining military weapons from Czechoslovakia and concern for Israel's security. One week later, President Nasser nationalized the Suez Canal and set in motion the Suez crisis. The USSR assumed the constructions costs for the Aswan project. Henceforth, Moscow became the primary supplier of weaponry to both Egypt and Syria. 
Russia delivered a long-promised S-300 surface-to-air missile system to Syria ${ }^{21}$. The delivery of this system had been promised in 2011 but didn't materialize due to objections by Israel and the United States. Russia appeared to be sending a message that its neutrality regarding Israeli air operations in Syria was over. Would the Americans abandon their trustworthy and battlefield successful Kurdish allies? They did just that! Would Turkey seek to block further Kurdish success in northern Syria? They did just that! Would Russia press on with its air campaign to help the Assad forces recover lost territory? They have done just that and vigorously so.

Simultaneously, the refugee crisis threatens to destroy European Community cohesiveness and common goals. Lebanon, Jordan and even Turkey are facing serious internal fissures due to the influx of Syrian refugees. Washington wants to quit the region but not at the expense of putting Israel at more risk. Iraq has had new elections and continues with a Shia-dominated government still friendly with Iran. The Syrian opposition maintains its firm but increasingly unrealistic stance that the Assad regime must go before it will talk about the future. President Assad and his Russian allies prepare for the final battle in northwestern Idlib Province. Israel continues its unrealistic stance that Iran must abandon Syria or at the least remove all of its military from the country. Israel threatens to destroy Lebanon if Hezbollah continues to strengthen itself militarily in defense against promised Israeli intrusions.

Washington, governing the world's most nuclear armed country, in not so subtle ways threatens to remove the Iranian regime if it restarts its nuclear weapons program. All the while Syria suffers. The potential for the United States and Russia to engage in armed conflict over what happens in Syria is serious. Threat of a World War III no longer can be ignored.

\section{A future fraught with problems}

The September 23, 2018 Russia-Turkey agreement in Sochi, Russia is an attempt to defuse an approaching government invasion and inevitable tragedy for all concerned in Syria's northwestern Idlib Province. The agreement to establish

${ }^{21}$ J. Marcus (2018). Initially promised in 2011, a Russian S-300 surface-to-air missile system was finally delivered to its Syrian ally in spite of sharp opposition by the United States and Israel. What prompted the delivery at this particular time was the downing of a Russian Ilylushin electronic intelligence gathering plane and the deaths of its crew by Syrian air defense units aiming at Israeli aircraft attacking nearby targets in Syria. Russia claimed that the Israeli planes were using the downed Russian plane as cover. Apparently some voices in the Russian Defense Ministry were advocating direct retaliatory attacks on airfields in Israel proper. "BBC News", September 24, 2018, https://www.bbc.com/new/ world-middle-east-45625388 
a 15-20 kilometer demilitarized zone between government and rebel forces and the withdrawal of all tanks, artillery, mortars and multiple launch rocket systems by October 10, 2018 ${ }^{22}$ was tenuous and already has failed ${ }^{23}$. The agreement also calls for joint Russian-Turkish military patrols to insure the keeping of the terms of the agreement. The Sochi agreement is fraught with serious and longer-term danger. By constraining Damascus in seeking recovery of the last significant part of Syria not under government control, this agreement sanctions what likely could be a permanent opposition-controlled piece of Syrian territory. This is intolerable for a regime that has suffered so much and for so long along with millions of Syrians, whether pro-government or anti-Assad. The agreement essentially codifies a permanent opposition government in situ (in Syria proper). No mention has been made regarding a process or timetable to remove or eliminate the scores of ISIS fighters presently in Idlib Province. Who will do the cleansing?

Too often the Syrian opposition has been co-opted by ISIS or its affiliates to fight the regime. If and when ISIS is effectively removed from Idlib, will the 'moderate' opposition be permitted to maintain its weaponry or to import new arms? For that matter, will they be permitted to continue political agitation? Turkey is the logical entry point for weapons and policing but its past role in facilitating entry into Syria of foreign jihadists puts to question its objectivity. Furthermore, best not to forget the pre-conflict population in Idlib. Their numbers have been greatly increased by ISIS, opposition fighters and their families. These people evacuated other areas under attack by Russia and the regime and accepted safe conduct passage to what has amounted to the Idlib dumping ground for defeated insurgents. Once provided with security, will any appreciable numbers of displaced Syrians in Idlib accept government assurances to live in peace elsewhere in the country? ${ }^{24}$. Accepting a permanent cancer to its national integrity may be asking too much of a regime that has seen so many tragedies prior to its more recent military successes. Russia and even allied Iran may need to reassess this agreement with Turkey. It cannot stand the test of time.

${ }^{22}$ J. Macaron (2018).

${ }^{23}$ Rebels fire shells from Syria buffer despite heavy arms pullout: activists, "The Daily Star" (Beirut), October 24, 2018. See also Syrian rebels hold out in final enclave, "The Wall Street Journal" (World News), October 16, 2018.

${ }^{24}$ Syria offers amnesty to deserters and draft dodgers, "The Daily Star" (Beirut), October 9, 2018. Amnesty covers Syrians in and out of the country. The proclamation does not include 'criminals' and army defectors some of whom are still fighting against the government. Deserters and draft dodgers in Syria have four months and those abroad have six months to turn themselves in to the authorities. 


\section{Summary}

The lands of the eastern Mediterranean are storied for their historical lore. Birthplace for two important religions, the objective for the great crusades seeking religious-political transformation, the carving-up of the last of the great empires centered in Constantinople, this area has now drawn Washington's interest if only half-throttle. Seldom has there existed a more confused and convoluted array of players and purported objectives. The Arab Spring that began with such high hope in Tunisia soon stuttered to a slow shift once the West and the United States in particular recognized some of the negative collateral implications to regime change. Military rule was more reliable than what many viewed as mob rule with no consideration for political alliances or special interests.

Short-lived, the Arab Spring emerged from the discontent of the masses and initially caused great excitement in the Arab-speaking world and elsewhere. Longstanding dictatorial rule was at risk as was the region's geopolitical fabric that emerged following World War I. Also at risk were the Egyptian-Israeli linkages resulting from the 1973 war and follow-up endeavors by President Carter in the Camp David meetings with President Sadat and Prime Minister Begin. Initial euphoria over free elections in Egypt and the arrest of President Mubarak soured early in President Morsi's tenure. He sought a different parameter for the country's external relations, Israel and Hamas in particular. This clearly was of concern in Washington. Whether the United States had a hand in Morsi's overthrow is irrelevant. The fact of the matter is that the military takeover of the country's first elected president, while condemned, did not stop Washington from renewing military assistance and providing diplomatic recognition. Was Washington's about-face due to incidents related to persecution of Coptic Christians or sabotage of gas pipelines serving Israel's energy needs? Anti-Israeli incidents were increasing, and Morsi's government seemed unable or unwilling to bring the situation under control.

From the outset, Syria seemed to be a special problem. Scores of disaffected citizens rallied to the spirit of the Arab Spring; poorly thought-out, heavy-handed responses by Damascus served only to inflame an increasingly combustible situation. Relying on the minority Alawites and other fringe confessional groups for core support, the government was faced with significant opposition from within the majority Sunni population including many moderates and most fundamentalists. The Assad regime had long maintained control with force and exhibited little tolerance for Islamic fundamentalism in a secular country with numerous ethnic and confessional flashpoints. Defections from the Syrian army and disaffection with the regime added to the ranks of those in opposition to Assad rule. Yet it appears that the majority of Syria's population supported the government, fearful of the consequences that might follow with a less tolerant leadership. Unlike Tunisia, Egypt or Algeria in its earlier ill-fated prelude to 
an Arab Spring where the citizenry seeking change clearly were in a majority, the situation in Syria was less clear. Even the outgoing American Ambassador in Damascus admitted that at least $60 \%$ of the country's population supported the Assad regime. This figure is given still greater credence by assessments that the great majority of Syrians who fled civil war into neighboring countries would choose to live in government controlled areas were they comfortable in returning.

\section{References}

Al-Maghafi N., 2018, How chemical weapons have helped bring Assad to victory, BBC-BBC Arabic Panorama, October 14, 2018.

Can it get together? Syria's disparate opposition must unite if it is to topple the regime, "The Economist" (Middle East and Africa), September 3, 2011.

Durham W.D, 2010, The 1920 Treaty of Sevres and the Struggle for a Kurdish Homeland in Iraq and Turkey between the World Wars, Ph.D. Dissertation Oklahoma State University, July, 2010.

Fayez J.A., 2015, The colonization of Palestine: Lest the civilized world forget, "Americans for Middle East Understanding", New York.

Fisk R., 1997, A Land in the Shadow of Death, "The Independent" (UK), January 19, 1997.

Fisk R., 2006, The Great War for Civilisation: The Conquest of the Middle East, Alfred A. Knopf, New York.

Fisk R., 2012, Syria is used to the slings and arrows of friends and enemies, "The Independent" (UK), February 1, 2012.

Hardy R., 2005, The Iran-Iraq war: 25 years on, https://news.bbc.co.uk/go/pr/fr/-/2hi/ middle_/4260420stm

Khalidi W., 1984, Before Their Diaspora: A Photographic History of The Palestinians 1876-1948, Institute for Palestine Studies, Washington D.C.

Laqueur W.Z., 1958, The Middle East in Transition, Routledge \& Kegan Paul, London.

Laqueur W., 1969, The Israel-Arab Reader: A Documentary History of the Middle East Conflict, Bantam, New York.

Lochner L., 1942, What about Germany?, Dodd, Mead \& Co., New York.

Macaron J., 2018, Sochi Agrement on Idlib Tests Russan-Turkish Relation, Arab Center, Washington, D.C. October 19, 2018, http://www.ArabCenterdc.org/policy-analyses/ sochi-agreement-on-idlib-tests-russian-turkish-relations/

Marcus J., 2018, Is Russia taking control of Syria's air defences?, BBC News, September 24, 2018.

Milton G., 2008, Paradise Lost: Smyrna 1922. The Destruction of a Christian City in the Islamic World, Basic Books, New York.

Morgenthau H., 1918, Ambassador Morgenthau's Story, Doubleday, Page \& Co., New York. 
New Lockerbie Report says Libyan (Abdelbaset al-Megrahi) was framed to conceal real bombers, "The Independent" (London), March 11, 2014.

Rebels fire shells from Syria buffer despite heavy arms pullout: activists, "The Daily Star" (Beirut), October 24, 2018.

Roberts D., 1994, The Holy Land: Yesterday and Today. Lithographs and Diaries by David Roberts, R.A., The American University in Cairo Press, Cairo.

Syria offers amnesty to deserters and draft dodgers, "The Daily Star" (Beirut), October 9, 2018.

Syrian Rebels Hold Out in Final Enclave, "The Wall Street Journal" (World News), October 16, 2018.

Trump warns Syria not to 'recklessly' attack Idlib Province, “The Daily Star" (Beirut), September 4, 2018.

We Don't Give a Dam - The Feud over Financing the Aswan High Dam-Moments in U.S. Diplomatic History, "Association of Diplomatic Studies and Training”, June, 2016.

World War I Document Archive, Brigham Young University, Provo, Utah.

\section{Internet sources}

http://www.hri.org./docs/king-crane-recomm.html

https://en.wikipedia.org/wiki/King-Crane_Commission

https://en.wikipedia.org/wiki/San_Remo_conference

https://www.balfourproject.org/the-mcmahonpromise

https:/www.bbc.com/new/world-middle-east

https://www.independent.co.uk/news/uk/crime/new-lockerbie-report-says-libyan-was-

framed-to-conceal-the-real-bombers-9185163.htnl

\section{Przypadek Syrii: rozpad nowoczesnego państwa w dobie fałszywych wiadomości i regionalnej rywalizacji supermocarstw}

Zarys treści: Negatywny wpływ globalizacji łatwo zauważyć w dzisiejszej Syrii. Artykuł poświęcony jest siedmioletniemu konfliktowi wewnętrznemu, którego początek był reakcją na wydarzenia w Tunezji zwane arabskim przebudzeniem. Syria, niegdyś dobrze funkcjonujące państwo, stała się magnesem dla fanatyków religijnych i ich bogatych sponsorów z konserwatywnej Arabii Saudyjskiej i innych odległych państw szukających korzyści geopolitycznych. Syria doświadczyła daremnych starań podejmowanych przez ONZ w celu trwałego rozwiązania konfliktu w tym kraju. Interwencja wojskowa Iranu i Rosji zmieniła konfigurację konfliktu w krytycznym momencie, podczas gdy interwencja Izraela i Stanów Zjednoczonych stanowi zagrożenie konfliktem supermocarstw. Przez cały czas Syryjczycy pozostający w tym kraju cierpią, a ci, którzy szukają bezpieczeństwa gdzie indziej, stanowią zagrożenie dla stabilizacji politycznej Libanu, Turcji i Jordanii, a w dalszej perspektywie także dla spójności polityki Unii Europejskiej. 
Słowa kluczowe: Syria, Iran, Turcja, Izrael, arabska wiosna, terroryzm, geopolityka regionalna, problem kurdyjski, uchodźcy, konfrontacja supermocarstw.

William R. Stanley

University of South Carolina, USA

Department of Geography

e-mail: stanleyb@mailbox.sc.edu 